\title{
Carrier frequency of $G J B 2$ (connexin-26) mutations causing inherited deafness in the Korean population
}

\author{
Sung-Hee Han · Hong-Joon Park · Eun-Joo Kang • \\ Jae-Song Ryu • Anna Lee $\cdot$ Young-Ho Yang · \\ Kyoung-Ryul Lee
}

Received: 8 April 2008/Accepted: 19 October 2008/Published online: 2 December 2008

(C) The Japan Society of Human Genetics and Springer 2008

\begin{abstract}
Mutations in the $G J B 2$ gene are associated with hereditary hearing loss. Although most studies of GJB2 mutations have dealt with hearing-impaired patients, there are few reports of the frequency of these mutations in the general population. The purpose of this study is to evaluate the prevalence of $G J B 2$ mutations causing inherited deafness in the general Korean population. Blood samples were obtained from 2,072 newborns with normal hearing. The dried blood samples were subjected to PCR to amplify the entire coding region of the GJB2 gene, which was followed by direct DNA sequencing. A total of 24 different sequence variants were identified in the coding region of GJB2, including eight pathogenic mutations (p.V37I, p.G45E, p.R143 W, c.176_191del16, c.235delC, c.292_298dup7, c.299_300delAT and c.605ins46), four polymorphisms (p.V27I, p.E114G, p.G160S and p.I203T), six unclassified variants (p.G4D, p.S85Y, p.T123 N, p.R127H, p.A171T and p.F191L) and six novel variants (p.W3T, p.I20L, p.K41E, c.147C > T, c.186C $>\mathrm{T}$ and c.576A $>$ G). Pathogenic mutations causing inherited deafness were identified in $3 \%(62 / 2,072)$ of the newborns with normal hearing. Of the eight pathogenic mutations found, p.V37I
\end{abstract}

S.-H. Han - E.-J. Kang - J.-S. Ryu - A. Lee · Y.-H. Yang ·

K.-R. Lee $(\bowtie)$

Division of Molecular Genetics,

Department of Laboratory Medicine,

Seoul Clinical Laboratories,

Seoul Medical Science Institute,

7-14, Dongbingo-dong, Yongsan-gu,

Seoul, South Korea

e-mail: dkrlee@scllab.co.kr

H.-J. Park

Department of Otorhinolaryngology,

Soree Ear Clinic, 46-16, Chungdam-dong,

Kangnam-gu, Seoul, South Korea was the most common $(1.35 \%, 28 / 2,072)$, followed by c. $235 \mathrm{delC}(1.25 \%, 26 / 2,072)$. These data provide information about carrier frequency for GJB2-based hearing loss and have important implications for genetic diagnostic testing for inherited deafness in the Korean population.

Keywords Carrier frequency - GJB2 .

Inherited deafness $\cdot$ Korean

\section{Introduction}

Hearing impairment is a common disorder that affects approximately 1 in 1,000 children, and about $50 \%$ of the cases are of genetic origin (Petit et al. 2001). Genetic deafness is highly heterogeneous, with more than 100 genes predicted to cause this disorder in humans (Steel and Kros 2001). In spite of this large genetic heterogeneity, mutations in the GJB2 gene encoding connexin 26 (Cx26) are responsible for approximately half of the cases of severe-to-profound autosomal-recessive, non-syndromic hearing loss in many populations (Van Camp et al. 1997; Zelante et al. 1997). Published mutations and polymorphisms in GJB2 and other connexin-encoding genes are available at the connexin-deafness home page (http://davinci.crg.es/deafnss/). More than 90 different GJB2 mutations have been described to be associated with recessive forms of non-syndromic hearing loss thus far. A single mutation of this gene (c.35delG) accounts for approximately $70 \%$ of the mutations in Caucasians, with a carrier frequency of 2-4\% in Europe (Zelante et al. 1997; Green et al. 1999; Lucotte and Diéterlen 2005). Conversely, it is less frequent or even absent in other ethnic groups. In these other groups, different mutations prevail: for instance, c.235delC displays a carrier frequency of 
1-2\% in the Japanese population (Abe et al. 2000; Ohtsuka et al. 2003); c.167delT has a carrier frequency of $4.03 \%$ in the Ashkenazi Jewish population (Morell et al. 1998); p.V37I has a carrier frequency of $8.5 \%$ in the Thai population (Wattanasirichaigoon et al. 2004). In the present study, we have investigated the carrier frequency of the GJB2 (connexin-26) mutations causing inherited deafness in the general Korean population. This is the first study of deafness-related mutations conducted with the aim to evaluate carrier frequency in this country.

\section{Materials and methods}

In total, 2,072 subjects from the Korean neonatal screening program for metabolic disorders were selected, beginning in 2006. All subjects showed normal responses in their transient evoked otoacoustic emissions (TEOAEs). Informed consent was obtained from the parents of all subjects. Whole blood was obtained from each child and dried on filter-paper cards. The cards were rendered anonymous, assigned a random number, and then the blood samples were used for DNA extraction. To identify GJB2 mutations, DNA fragments containing the entire coding region were amplified using the two sets of primers for exon 2: set 1 (forward primer: GTC TCC CTG TTC TGT CCT AG; reverse primer: CTT CGA AGA TGA CCC GGA AG) and set 2 (forward primer: TCA AGG GGG AGA TAA AGA GTG; reverse primer: TGA GCA CGG GTT GCC TCA TC). The PCR products were used to produce a template for sequencing. PCR conditions were as follows: reaction volume, $25 \mu \mathrm{l}$; primers, $10 \mathrm{pM}$; template genomic DNA, $100 \mathrm{ng}$; denaturation at $94^{\circ} \mathrm{C}$ for $5 \mathrm{~min}$ and at $94^{\circ} \mathrm{C}$ for $40 \mathrm{~s}$; at $53^{\circ} \mathrm{C}$ for $40 \mathrm{~s}$ and $72^{\circ} \mathrm{C}$ for $55 \mathrm{~s}$ for 35 cycles followed by a 3 -min final extension at $72^{\circ} \mathrm{C}$. The products of PCR were electrophoresed on $2 \%$ agarose gel and visualized with ethidium bromide staining under ultraviolet light to verify their size and quantity. They were sequenced with the Applied Biosystems (ABI) Prism BigDye Terminator Cycle Sequencing Kit and ABI 3100 DNA sequencer (PE Applied Biosystems, Foster City, CA) using the same forward and reverse primers. All PCR products were sequenced in both directions. Sequence variants in $G J B 2$ are described according to the nomenclature recommendations of den Dunnen and Antonarakis (2001) and Ogino et al. (2007). Novel missense variants identified in this study were analyzed using the PolyPhen (http://genetics.bwh.harvard.edu/pph/) and SNPs3D (http:// www.snps3d.org/) prediction software. The carrier frequency of the c.235delC found in this study was compared with that of other Asian populations using the $95 \%$ confidence interval of carrier frequency based on binomial probability distribution (Leemis and Trivedi 1996).

\section{Results}

DNA from a total of 2,072 unrelated newborns with normal hearing $(4,144$ chromosomes) was sequenced for the coding region of $G J B 2$. From these samples, 24 different sequence variants were identified, which were subclassified as 19 nontruncating and 5 truncating mutations. No sequence variants were found in $27.7 \%(573 / 2,072)$ of the samples. Eight pathogenic mutations including one novel mutation, c.292_298dup7 (p.H100PfsX4), were found in samples from 62 subjects $(3 \%)$ in a heterozygous state (Table 1): four frameshift mutations, c.176_191del16, c.235delC, c.292_298dup7 and c.299_300delAT; one insertion mutation, c.605ins46; and three missense mutations, p.V37I, p.G45E and p.R143 W.

With a carrier frequency of $1.35 \%(28 / 2,072)$ among the subjects, p.V37I was the most frequent pathogenic mutation, followed by c.235delC (p.L79CfsX3) (1.25\%, 26/2,072). The novel mutation, c.292_298dup7 (p.H100PfsX4), was found in one subject. This duplication causes a frameshift at codon 100, resulting in termination at codon 103. The other deletion, c.299_300delAT (p.H100RfsX14), which causes a frameshift leading to an altered amino acid sequence from codon 100 , followed by a stop at codon 113, was found in $3(0.14 \%)$ of the 2,072 subjects in this study. Of the missense mutations, p.G45E $($ c.134G > A) and p.R143 W (c.427C > T) were each detected in one subject. No subject was homozygous or compound heterozygous for any pathogenic mutation.

Four polymorphisms (p.V27I, p.E114G, p.G160S and p.I203T) were also found in the coding region of GJB2. The p.V27I (allele frequency $=37.36 \%$ ) and p.E114G (allele frequency $=19.64 \%$ ) variants were the most common alleles detected in this study. Six unclassified variants, p.G4D, p.S85Y, p.T123 N, p.R127H, p.A171T and p.F191L, were also identified among the subjects, and six novel variants including three missense (p.W3T, p.I20L and p.K41E) and three silent variants (c.147C $>\mathrm{T}$, c. $186 \mathrm{C}>\mathrm{T}$ and c.576A $>\mathrm{G}$ ) were found (Table 1). The PolyPhen prediction tool predicts p.W3T to be probably damaging, while p.I20L and p.K41E are predicted to be benign (data not shown). SNPs3D predicts that the p.W3T would be deleterious, while p.I20L and p.K41E would be non-deleterious (data not shown). Both prediction tools gave similar results. Forty-two percent of the subjects carried two to four DNA sequence variants in the coding region of GJB2. The p.V27I/p.E114G compound heterozygote was the most common genotype $(31.8 \%, 659 /$ 2,072).

As shown in Table 2, the carrier frequency of the c. $235 \mathrm{delC}$ was calculated to be $1.25 \%$ with $95 \%$ binomial CI, 0.82-1.83. Compared to other Asian populations, this frequency proved to be similar to that found in the Chinese 
Table 1 GJB2 sequence variants detected in 2,072 newborn dried blood spots

\begin{tabular}{|c|c|c|c|c|c|c|}
\hline \multirow[t]{2}{*}{ Amino acid variation } & \multirow[t]{2}{*}{ Nucleotide variation } & \multirow[t]{2}{*}{ Protein domain } & \multirow[t]{2}{*}{ Characterization of variant } & \multicolumn{3}{|c|}{ Total allele no. $=4,144$} \\
\hline & & & & Heterozygote & Homozygote & Allele no. (\%) \\
\hline \multicolumn{7}{|l|}{ Nontruncating } \\
\hline $\mathrm{W} 3 \mathrm{~T}^{\mathrm{a}}$ & $9 \mathrm{G}>\mathrm{A}$ & IC1 & Pathogenic ${ }^{e, f}$ & 1 & & $1(0.02)$ \\
\hline G4D & $11 \mathrm{G}>\mathrm{A}$ & IC1 & Unclassified & 1 & & $1(0.02)$ \\
\hline $\mathrm{I} 20 \mathrm{~L}^{\mathrm{a}}$ & $58 \mathrm{~A}>\mathrm{G}$ & IC1 & Polymorphism $^{\mathrm{e}}$ & 1 & & $1(0.02)$ \\
\hline V27I & $79 \mathrm{G}>\mathrm{A}$ & TM1 & Polymorphism & 1,112 & 218 & $1548(37.36)$ \\
\hline V37I & $109 \mathrm{G}>\mathrm{A}$ & TM1 & Pathogenic & 28 & & $28(0.68)$ \\
\hline $\mathrm{K} 41 \mathrm{E}^{\mathrm{a}}$ & $121 \mathrm{~A}>\mathrm{G}$ & $\mathrm{EC} 1$ & Polymorphism $^{\mathrm{e}}$ & 1 & & $1(0.02)$ \\
\hline G45E & $134 \mathrm{G}>\mathrm{A}$ & $\mathrm{EC} 1$ & Pathogenic & 1 & & $1(0.02)$ \\
\hline $\mathrm{A} 49 \mathrm{~A}^{\mathrm{a}}$ & $147 \mathrm{C}>\mathrm{T}$ & $\mathrm{EC} 1$ & Polymorphism $^{\mathrm{e}}$ & 1 & & $1(0.02)$ \\
\hline $\mathrm{N} 62 \mathrm{~N}^{\mathrm{a}}$ & $186 \mathrm{C}>\mathrm{T}$ & $\mathrm{EC} 1$ & Polymorphism $^{\mathrm{e}}$ & 1 & & $1(0.02)$ \\
\hline S85Y & $254 \mathrm{C}>\mathrm{A}$ & TM2 & Unclassified & 1 & & $1(0.02)$ \\
\hline E114G & $341 \mathrm{~A}>\mathrm{G}$ & $\mathrm{IC} 2$ & Polymorphism & 660 & 77 & 814 (19.64) \\
\hline $\mathrm{T} 123 \mathrm{~N}$ & $368 \mathrm{C}>\mathrm{A}$ & $\mathrm{IC} 2$ & Unclassified & 5 & & $5(0.12)$ \\
\hline $\mathrm{R} 127 \mathrm{H}$ & $380 \mathrm{G}>\mathrm{A}$ & $\mathrm{IC} 2$ & Unclassified & 1 & & $1(0.02)$ \\
\hline R143 W & $427 \mathrm{C}>\mathrm{T}$ & TM3 & Pathogenic & 1 & & $1(0.02)$ \\
\hline G160S & $478 \mathrm{G}>\mathrm{A}$ & $\mathrm{EC} 2$ & Polymorphism & 1 & & $1(0.02)$ \\
\hline $\mathrm{A} 171 \mathrm{~T}$ & $511 \mathrm{G}>\mathrm{A}$ & $\mathrm{EC} 2$ & Unclassified & 1 & & $1(0.02)$ \\
\hline F191L & $571 \mathrm{~T}>\mathrm{C}$ & TM4 & Unclassified & 2 & & $2(0.05)$ \\
\hline $\mathrm{T} 192 \mathrm{~T}^{\mathrm{a}}$ & $576 \mathrm{~A}>\mathrm{G}$ & TM4 & Polymorphism ${ }^{\mathrm{e}}$ & 1 & & $1(0.02)$ \\
\hline $\mathrm{I} 203 \mathrm{~T}$ & $608 \mathrm{~T}>\mathrm{C}$ & TM4 & Polymorphism & 137 & 5 & $147(3.55)$ \\
\hline \multicolumn{7}{|l|}{ Truncating } \\
\hline G59AfsX18 & $176 \_191 \mathrm{del} 16^{\mathrm{b}}$ & $\mathrm{EC} 1$ & Pathogenic & 1 & & $1(0.02)$ \\
\hline L79CfsX3 & 235 delC & TM2 & Pathogenic & 26 & & $26(0.63)$ \\
\hline $\mathrm{H} 100 \mathrm{Pfs} X 4^{\mathrm{a}}$ & 292_298dup7 & $\mathrm{IC} 2$ & Pathogenic $^{\mathrm{e}}$ & 1 & & $1(0.02)$ \\
\hline H100RfsX14 & $299 \_300 \mathrm{del}^{\mathrm{A}} \mathrm{T}^{\mathrm{c}}$ & $\mathrm{IC} 2$ & Pathogenic & 3 & & $3(0.07)$ \\
\hline $\mathrm{C} 202 \mathrm{X}$ & $605 \operatorname{ins} 46^{d}$ & TM4 & Pathogenic & 1 & & $1(0.02)$ \\
\hline
\end{tabular}

IC intracellular, TM transmembrane, EC extracellular

${ }^{a}$ Novel sequence variant

b The c.176_191del16 mutation was previously identified in Korean and Japanese individuals with nonsyndromic hearing loss (Park et al. 2000; Abe et al. 2000; Ohtsuka et al. 2003)

c The c.299-300delAT mutation has been reported, mainly Asians (Abe et al. 2000; Park et al. 2000)

${ }^{\mathrm{d}}$ One insertion mutation, c.605ins46, was previously found in a Japanese family with hearing loss (Yuge et al. 2002) and in a newborn with hearing loss in Northern China (Shi et al. 2004)

e Classified in terms of their pathogenicity based on the PolyPhen and SNPs3D prediction softwares

${ }^{\mathrm{f}}$ The p.W3T was described as novel variant in the text and not counted for the carrier frequency of GJB2 pathogenic mutations

(total carrier frequency, 1.05\%), Japanese (total carrier frequency, $1.65 \%$ ) and previously studied Korean populations (1\%), but was higher than that of the Thai population $(0.49 \%)$ and lower than that of the population of the Altai Republic (4.62\%) (Liu et al. 2002; Xiao and Xie 2004; Dai et al. 2007; Abe et al. 2000; Ohtsuka et al. 2003; Wattanasirichaigoon et al. 2004; Posukh et al. 2005; Park et al. 2000). In addition, the carrier frequency of the c.235delC found in this study is similar to that detected in the overall Asian population (1.32\%, 95\% binomial CI, 0.96-1.76).

\section{Discussion}

The mutation spectrum in the GJB2 gene in the Asian population is significantly different from that found in ethnic groups of European ancestry. In this study, we evaluated the prevalence of GJB2 mutations causing inherited deafness in the Korean population, and eight different variants associated with inherited deafness were identified. The carrier frequency of GJB2 pathogenic mutations was $3 \%$ in 2,072 unrelated newborns with 
Table 2 Carrier frequency of the $235 \mathrm{del} C$ mutation in different Asian populations

${ }^{\text {a }}$ Unrelated individuals with normal hearing confirmed by auditory testing

\begin{tabular}{lcllll}
\hline Populations & $\begin{array}{l}\text { Subjects }^{\mathrm{a}} \\
\text { tested }^{2}\end{array}$ & $\begin{array}{l}\text { 235delC } \\
\text { Heterozygote }\end{array}$ & $\begin{array}{l}\text { Carrier } \\
\text { frequency }(\%)\end{array}$ & $\begin{array}{l}\text { 95\% CI binomial } \\
\text { distribution }\end{array}$ & References \\
\hline Chinese-1 & 200 & 1 & 0.5 & $0.01-2.75$ & Liu et al. (2002) \\
Chinese-2 & 100 & 1 & 1 & $0.02-5.45$ & Xiao and Xie (2004) \\
Chinese-3 & 368 & 5 & 1.36 & $0.44-3.14$ & Dai et al. (2007) \\
Japanese-1 & 96 & 2 & 2.08 & $0.25-7.32$ & Abe et al. (2000) \\
Japanese-2 & 147 & 2 & 1.36 & $0.17-4.83$ & Ohtsuka et al. (2003) \\
Thai & 205 & 1 & 0.49 & $0.01-2.69$ & Wattanasirichaigoon et al. \\
& & & & & (2004) \\
Altai Republic & 130 & 6 & 4.62 & $1.71-9.78$ & Posukh et al. (2005) \\
Korean-1 & 100 & 1 & 1 & $0.02-5.45$ & Park et al. (2000) \\
Korean-2 & 2,072 & 26 & 1.25 & $0.82-1.83$ & Present study \\
Asian (overall) & 3,418 & 45 & 1.32 & $0.96-1.76$ & Present study \\
\hline
\end{tabular}

normal hearing, which is similar to that found in the Caucasian population (2-3\%) (Kelley et al. 1998; Green et al. 1999; Tang et al. 2006). Taking into account this carrier frequency, 1 in every 4,468 subjects of the Korean general population would be homozygous or compound heterozygous for GJB2 mutations that cause inherited deafness.

The predominant mutation of GJB2 among East Asian populations is c.235delC (Fuse et al. 1999; Abe et al. 2000; Park et al. 2000; Liu et al. 2002). In the present study, 26 of the 2,072 subjects $(1.25 \%)$ were found to be carriers of the c.235delC mutation. In the study of Park et al. (2000), c. $235 \mathrm{delC}$ was found in one heterozygote (1\%) among 100 normal controls, which is similar to the findings of this study. As shown in Table 2, this is a lower rate than those of Korea's neighboring countries, Japan and the Altai Republic (which has a very mixed population, including Altian, Russian and mixed ethnicity) (Abe et al. 2000; Ohtsuka et al. 2003; Posukh et al. 2005). However, this is a higher rate than that of China and Thailand (Liu et al. 2002; Xiao and Xie 2004; Dai et al. 2007; Wattanasirichaigoon et al. 2004). Yan et al. (2003) previously investigated a possible founder effect for c.235delC, which seems to be a unique mutation in Asian populations, including the Chinese, Japanese, Korean and Mongolian populations. A low frequency or absence of c.235delC carriers has been reported in the Caucasian population (Green et al. 1999; Yan et al. 2003; Tang et al. 2006). The c.35delG mutation was not found in this study performed on 2,072 newborns with normal hearing. In the other Korean study by Park et al. (2000), there were two heterozygotes in 147 patients with non-syndromic hearing loss and one heterozygote in 100 normal controls.

The most frequent pathogenic mutation identified was p.V37I, with a carrier frequency of $1.35 \%$ in this study. Considering the genotype, the pathogenicity of the c.235delC mutation has been well-established because it results in a shift of the reading frame with premature termination of translation. The p.V37I variant, on the other hand, was originally described as a polymorphism because it was identified in an unaffected heterozygous control (Kelley et al. 1998). It has a high allele frequency in several populations (Ohtsuka et al. 2003; Hwa et al. 2003; Roux et al. 2004). Over time, however, the mutation has been identified in numerous homozygous and compound heterozygous individuals with hearing loss (Wu et al. 2002). The hearing loss was progressive in at least one severely affected patient who was homozygous p.V37I/ p.V37I (Bason et al. 2002). Furthermore, the affected Valine residue in the first transmembrane domain is conserved throughout the beta-connexins (Rabionet et al. 2000). Additionally, functional studies of electrical conductance between paired Xenopus oocytes showed that the mutation is devoid of function, which strongly supports pathogenicity (Bruzzone et al. 2003; Palmada et al. 2006). The p.V37I variant is classified as a mutation that causes a less severe phenotype than c. $235 \mathrm{delC}$, but that does result in mild-to-moderate hearing impairment in the compound heterozygous state (c.235delC/p.V37I) (Oguchi et al. 2005; Schrijver and Chang 2006). Recently, p.V37I was again proposed to be pathogenic since it was found to be overrepresented among individuals with mild hearing impairment compared to ethnically matched controls, although the data were limited to subjects of Asian descent (Dahl et al., 2006; Huculak et al. 2006). So far, p.V37I has been reported as a pathogenic change in mainly East Asians, including Japanese, Thai and Chinese individuals (Abe et al. 2000; Wattanasirichaigoon et al. 2004; Xiao and Xie 2004). However, in the other Korean study by Park et al. (2000), p.V37I was not found in 147 patients with non-syndromic severe-to-profound hearing loss and 100 controls. Also, the predominant mutation of GJB2 among East Asian populations was c.235delC, not p.V37I (Fuse et al. 1999; Abe et al. 2000; Liu et al. 2002). First, possible 
explanations for this discrepancy include selection bias, such as mild hearing loss with p.V37I homozygotes not included in the study by Park et al. (2000) and other previous studies of Asian populations (Fuse et al. 1999; Abe et al. 2000; Park et al. 2000; Liu et al. 2002). Second, the difference in allele frequencies may be the result of a difference in sample size in the studies. Third, p.V37I was associated with hearing impairment, but had significantly lower penetrance than other GJB2 mutations. There is also the possibility that p.V37I causes mild hearing impairment characterized by relatively late onset and progression (Pollak et al. 2007). Heterogeneity of hearing loss from mild to profound has been suggested to be correlated with the p.V37I variant. A multicenter study of GJB2 mutations and degree of hearing loss showed that the p.V37I variant was associated with mild hearing loss (Snoeckx et al. 2005). Recent functional studies of the GJB2 mutations (Bruzzone et al. 2003; Palmada et al. 2006) suggesting that the p.V37I variant is pathogenic, coupled with the high frequency of the p.V37I variant in this Korean population, support the likelihood that the pathogenic effect of the p.V37I variant is being modified by other gene(s) and/or environmental factors.

The novel mutation, c.292_298dup7 (p.H100PfsX4), results in truncation of the protein. In contrast to the number of point mutations, which is the most common type of $G J B 2$ mutation reported, GJB2 mutations by duplication of the nucleotide(s) have not been reported previously. The current report is, therefore, the first of a GJB2 mutation by duplication. The possible causes of this duplication may be a slipped mispairing or homologous unequal recombination (Antonarakis et al. 2001). The p.G45E mutation is a nonconservative substitution in the $\mathrm{N}$-terminal portion of the first extracellular loop of $\mathrm{Cx} 26$, in which most reported Keratitis-Ichthyosis-Deafness (KID) mutations are located (Griffith et al. 2006). This mutation has also been detected in Japanese individuals with non-syndromic recessive deafness (Abe et al. 2000; Oguchi et al. 2005). In this study, the p.G45E mutation was found in one subject with no known family history of KID syndrome or hearing loss. This mutation, p.R143 W, had initially been described as a pathogenic mutation with recessive inheritance (Brobby et al. 1998). Recent functional analyses demonstrated that p.R143 W was unable to form functional connexins, and there was no dominant negative effect on wild type Cx26, which would support a recessive character of this mutation (Meşe et al. 2004; Palmada et al. 2006).

Six previously reported unclassified variants, p.G4D, p.S85Y, p.T123 N, p.R127H, p.A171T and p.F191L, were identified in this study (Table 1). The p.G4D variant was previously reported by Roux et al. (2004) in a heterozygous state in one control and by Hwa et al. (2003) in a heterozygous state in seven Taiwanese patients. In the study of
Tang et al. (2006), the p.G4D variant was found in a heterozygous state in one Asian control and in one AfricanAmerican patient with no known family history of hearing loss. In this study, p.G4D was found in a heterozygous state in one subject. The p.T123 N variant was previously reported by Park et al. (2000) in a heterozygous state in one Korean patient and by Shi et al. (2004) in Northern Chinese patients and controls. In the study of Tang et al. (2006), the p.T123 $\mathrm{N}$ variant was found in a heterozygous state in one Asian control. In this study, the p.T123 N variant was found in a heterozygous state in five subjects. To clarify the exact role of these variants, careful follow-up and functional studies are needed. The significance of the mutation p.R127H for disease phenotype has been a matter of discussion. It was thought to be a polymorphism (Marlin et al. 2001; Thönnissen et al. 2002) as well as a recessive mutation (Estivill et al. 1998; D'Andrea et al. 2002; Wang et al. 2003) because of genetic evidence and cell culture assays. The functional data presented by Palmada et al. (2006) support the view that the mutation is relevant, since the p.R127H mutation showed significantly smaller currents than wild-type hemichannels. In the study of Roux et al. (2004), the p.R127H variants were found in a homozygous state in two normal-hearing individuals. Of the three novel missense variants (p.W3T, p.I20L and p.K41E), p.W3T is expected to be pathogenic, based on the findings of the PolyPhen and SNPs3D analyses, which suggested that substitution of amino acids might affect gap junction function. The three other novel variants (c.147C $>$ T, c.186C $>\mathrm{T}$ and c.576A $>$ G) are not expected to alter the amino acid sequence of $\mathrm{Cx} 26$. As a result, it is reasonable to predict that these sequence variants might be benign, unless they interrupt a regulatory element.

Complexity of genotypes was observed in this study (data not shown). Forty-two percent of the subjects carried two to four DNA sequence variants in the coding region of GJB2. The p.V27I/p.E114G compound heterozygote was the most common genotype $(31.8 \%, 659 / 2,072)$. The p.V27I polymorphism occurred without p.E114G in 462 individuals, while p.E114G occurred without p.V27I in only one individual. Seventy-seven individuals were homozygous for both p.V27I and p.E114G. These data suggest that p.V27I and p.E114G may frequently occur in cis.

In conclusion, the GJB2 pathogenic mutations in a Korean population were identified with a high carrier frequency (3\%) similar to that of Caucasian populations. The present study revealed the existence of eight different pathogenic mutations, including four frameshift, one nonsense and three missense mutations in the general Korean population. These results provide a fundamental basis for drawing a spectrum of $G J B 2$ mutation among the Korean 
population. Additionally, the diversity of $G J B 2$ mutations identified in this Korean population points to the importance of genetic testing by direct sequencing of the entire coding region.

\section{References}

Abe S, Usami S, Shinkawa H, Kelley PM, Kimberling WJ (2000) Prevalent connexin 26 gene (GJB2) mutations in Japanese. J Med Genet 37:41-43

Antonarakis SE, Krawczak M, Cooper DN (2001) The nature and mechanisms of human gene mutation. In: Scriver CR, Braudet AL, Sly WS, Vall DV (eds) The metabolic and molecular bases of inherited disease. McGraw-Hill, New York, pp 343-378

Bason L, Dudley T, Lewis K, Shah U, Potsic W, Ferraris A, Fortina P, Rappaport E, Krantz ID (2002) Homozygosity for the V37I Connexin 26 mutation in three unrelated children with sensorineural hearing loss. Clin Genet 61:459-464

Brobby GW, Müller-Myhsok B, Horstmann RD (1998) Connexin 26 $\mathrm{R} 143 \mathrm{~W}$ mutation associated with recessive nonsyndromic sensorineural deafness in Africa. N Engl J Med 338:548-550

Bruzzone R, Veronesi V, Gomès D, Bicego M, Duval N, Marlin S, Petit C, D'Andrea P, White TW (2003) Loss-of-function and residual channel activity of connexin 26 mutations associated with non-syndromic deafness. FEBS Lett 533:79-88

Dahl HH, Tobin SE, Poulakis Z, Rickards FW, Xu X, Gillam L, Williams J, Saunders K, Cone-Wesson B, Wake M (2006) The contribution of GJB2 mutations to slight or mild hearing loss in Australian elementary school children. J Med Genet 43:850-855

Dai P, Yu F, Han B, Yuan Y, Li Q, Wang G, Liu X, He J, Huang D, Kang D, Zhang X, Yuan H, Schmitt E, Han D, Wong LJ (2007) The prevalence of the 235delC GJB2 mutation in a Chinese deaf population. Genet Med 9:283-289

D'Andrea P, Veronesi V, Bicego M, Melchionda S, Zelante L, Di Iorio E, Bruzzone R, Gasparini P (2002) Hearing loss: frequency and functional studies of the most common connexin 26 alleles. Biochem Biophys Res Commun 296:685-691

den Dunnen JT, Antonarakis SE (2001) Nomenclature for the description of human sequence variations. Hum Genet 109:121-124

Estivill X, Fortina P, Surrey S, Rabionet R, Melchionda S, D'Agruma L, Mansfield E, Rappaport E, Govea N, Milà M, Zelante L, Gasparini P (1998) Connexin-26 mutations in sporadic and inherited sensorineural deafness. Lancet 351:394-398

Fuse Y, Doi K, Hasegawa T, Sugii A, Hibino H, Kubo T (1999) Three novel connexin 26 gene mutations in autosomal recessive nonsyndromic deafness. Neuroreport 10:1853-1857

Green GE, Scott DA, McDonald JM, Woodworth GG, Sheffield VC, Smith RJ (1999) Carrier rates in the midwestern United States for GJB2 mutations causing inherited deafness. JAMA 281:2211-2216

Griffith AJ, Yang Y, Pryor SP, Park HJ, Jabs EW, Nadol JB Jr, Russell LJ, Wasserman DI, Richard G, Adams JC, Merchant SN (2006) Cochleosaccular dysplasia associated with a connexin 26 mutation in keratitis-ichthyosis-deafness syndrome. Laryngoscope 116:1404-1408

Huculak C, Bruyere H, Nelson TN, Kozak FK, Langlois S (2006) V37I connexin 26 allele in patients with sensorineural hearing loss: evidence of its pathogenicity. Am J Med Genet A 140:2394-2400

Hwa HL, Ko TM, Hsu CJ, Huang CH, Chiang YL, Oong JL, Chen CC, Hsu CK (2003) Mutation spectrum of the connexin 26
(GJB2) gene in Taiwanese patients with prelingual deafness. Genet Med 5:161-165

Kelley PM, Harris DJ, Comer BC, Askew JW, Fowler T, Smith SD, Kimberling WJ (1998) Novel mutations in the connexin 26 gene (GJB2) that cause autosomal recessive (DFNB1) hearing loss. Am J Hum Genet 62:792-799

Leemis LM, Trivedi SK (1996) A Comparison of approximate interval estimators for the Bernoulli parameter. Am Stat 50:288295

Liu Y, Ke X, Qi Y, Li W, Zhu P (2002) Connexin 26 gene (GJB2): prevalence of mutations in the Chinese population. J Hum Genet 47:688-690

Lucotte G, Diéterlen F (2005) The 35delG mutation in the connexin 26 gene (GJB2) associated with congenital deafness: European carrier frequencies and evidence for its origin in ancient Greece. Genet Test 9:20-25

Marlin S, Garabédian EN, Roger G, Moatti L, Matha N, Lewin P, Petit C, Denoyelle F (2001) Connexin 26 gene mutations in congenitally deaf children: pitfalls for genetic counseling. Arch Otolaryngol Head Neck Surg 127:927-933

Meşe G, Londin E, Mui R, Brink PR, White TW (2004) Altered gating properties of functional Cx26 mutants associated with recessive non-syndromic hearing loss. Hum Genet 115:191-199

Morell RJ, Kim HJ, Hood LJ, Goforth L, Friderici K, Fisher R, Van Camp G, Berlin CI, Oddoux C, Ostrer H, Keats B, Friedman TB (1998) Mutations in the connexin 26 gene (GJB2) among Ashkenazi Jews with nonsyndromic recessive deafness. N Engl J Med 339:1500-1505

Ogino S, Gulley ML, den Dunnen JT, Wilson RB, The Association for Molecular Patholpogy Training, Education Committtee (2007) Standard mutation nomenclature in molecular diagnostics: practical and educational challenges. J Mol Diagn 9:1-6

Oguchi T, Ohtsuka A, Hashimoto S, Oshima A, Abe S, Kobayashi Y, Nagai K, Matsunaga T, Iwasaki S, Nakagawa T, Usami S (2005) Clinical features of patients with GJB2 (connexin 26) mutations: severity of hearing loss is correlated with genotypes and protein expression patterns. J Hum Genet 50:76-83

Ohtsuka A, Yuge I, Kimura S, Namba A, Abe S, Van Laer L, Van Camp G, Usami S (2003) GJB2 deafness gene shows a specific spectrum of mutations in Japan, including a frequent founder mutation. Hum Genet 112:329-333

Palmada M, Schmalisch K, Böhmer C, Schug N, Pfister M, Lang F, Blin N (2006) Loss of function mutations of the GJB2 gene detected in patients with DFNB1-associated hearing impairment. Neurobiol Dis 22:112-118

Park HJ, Hahn SH, Chun YM, Park K, Kim HN (2000) Connexin 26 mutations associated with nonsyndromic hearing loss. Laryngoscope 110:1535-1538

Petit C, Levilliers J, Hardelin JP (2001) Molecular genetics of hearing loss. Annu Rev Genet 35:589-646

Pollak A, Skórka A, Mueller-Malesińska M, Kostrzewa G, Kisiel B, Waligóra J, Krajewski P, Ołdak M, Korniszewski L, Skarzyński $\mathrm{H}$, Ploski R (2007) M34T and V37I mutations in GJB2 associated hearing impairment: evidence for pathogenicity and reduced penetrance. Am J Med Genet A 143A:2534-2543

Posukh O, Pallares-Ruiz N, Tadinova V, Osipova L, Claustres M, Roux AF (2005) First molecular screening of deafness in the Altai Republic population. BMC Med Genet 6:12-18

Rabionet R, Zelante L, López-Bigas N, D’Agruma L, Melchionda S, Restagno G, Arbonés ML, Gasparini P, Estivill X (2000) Molecular basis of childhood deafness resulting from mutations in the GJB2 (connexin 26) gene. Hum Genet 106:40-44

Roux AF, Pallares-Ruiz N, Vielle A, Faugère V, Templin C, Leprevost D, Artières F, Lina G, Molinari N, Blanchet $\mathrm{P}$, Mondain M, Claustres M (2004) Molecular epidemiology of DFNB1 deafness in France. BMC Med Genet 5:5 
Schrijver I, Chang KW (2006) Two patients with the V37I/235delC genotype: are radiographic cochlear anomalies part of the phenotype? Int J Pediatr Otorhinolaryngol 70:2109-2113

Shi GZ, Gong LX, Xu XH, Nie WY, Lin Q, Qi YS (2004) GJB2 gene mutations in newborns with non-syndromic hearing impairment in Northern China. Hear Res 197:19-23

Snoeckx RL, Huygen PL, Feldmann D, Marlin S, Denoyelle F, Waligora J, Mueller-Malesinska M, Pollak A, Ploski R, Murgia A, Orzan E, Castorina P, Ambrosetti U, NowakowskaSzyrwinska E, Bal J, Wiszniewski W, Janecke AR, NekahmHeis D, Seeman P, Bendova O, Kenna MA, Frangulov A, Rehm HL, Tekin M, Incesulu A, Dahl HH, du Sart D, Jenkins L, Lucas D, Bitner-Glindzicz M, Avraham KB, Brownstein Z, del Castillo I, Moreno F, Blin N, Pfister M, Sziklai I, Toth T, Kelley PM, Cohn ES, Van Maldergem L, Hilbert P, Roux AF, Mondain M, Hoefsloot LH, Cremers CW, Löppönen T, Löppönen H, Parving A, Gronskov K, Schrijver I, Roberson J, Gualandi F, Martini A, Lina-Granade G, Pallares-Ruiz N, Correia C, Fialho G, Cryns K, Hilgert N, Van de Heyning P, Nishimura CJ, Smith RJ, Van Camp G (2005) GJB2 mutations and degree of hearing loss: a multicenter study. Am J Hum Genet 77:945-957

Steel KP, Kros CJ (2001) A genetic approach to understanding auditory function. Nat Genet 27:143-149

Tang HY, Fang P, Ward PA, Schmitt E, Darilek S, Manolidis S, Oghalai JS, Roa BB, Alford RL (2006) DNA sequence analysis of GJB2, encoding connexin 26: observations from a population of hearing impaired cases and variable carrier rates, complex genotypes, and ethnic stratification of alleles among controls. Am J Med Genet 140:2401-2415

Thönnissen E, Rabionet R, Arbonès ML, Estivill X, Willecke K, Ott T (2002) Human connexin 26 (GJB2) deafness mutations affect the function of gap junction channels at different levels of protein expression. Hum Genet 111:190-197

Van Camp G, Willems PJ, Smith RJ (1997) Nonsyndromic hearing impairment: unparalleled heterogeneity. Am J Hum Genet 60:758-764
Wang HL, Chang WT, Li AH, Yeh TH, Wu CY, Chen MS (2003) Huang PC (2003) Functional analysis of connexin-26 mutants associated with hereditary recessive deafness. J Neurochem $84: 735-742$

Wattanasirichaigoon D, Limwongse C, Jariengprasert C, Yenchitsomanus PT, Tocharoenthanaphol C, Thongnoppakhun W, Thawil C, Charoenpipop D, Pho-iam T, Thongpradit S, Duggal $P$ (2004) High prevalence of V37I genetic variant in the connexin-26 (GJB2) gene among non-syndromic hearingimpaired and control Thai individuals. Clin Genet 66:452-460

Wu BL, Lindeman N, Lip V, Adams A, Amato RS, Cox G, Irons M, Kenna M, Korf B, Raisen J, Platt O (2002) Effectiveness of sequencing connexin 26 (GJB2) in cases of familial or sporadic childhood deafness referred for molecular diagnostic testing. Genet Med 4:279-288

Xiao ZA, Xie DH (2004) GJB2 (Cx26) gene mutations in Chinese patients with congenital sensorineural deafness and a report of one novel mutation. Chin Med J 117:1797-1801

Yan D, Park HJ, Ouyang XM, Pandya A, Doi K, Erdenetungalag R, Du LL, Matsushiro N, Nance WE, Griffith AJ, Liu XZ (2003) Evidence of a founder effect for the 235delC mutation of GJB2 (connexin 26) in east Asians. Hum Genet 114:44-50

Yuge I, Ohtsuka A, Matsunaga T, Usami S (2002) Identification of 605ins46, a novel GJB2 mutation in a Japanese family. Auris Nasus Larynx 29:379-382

Zelante L, Gasparini P, Estivill X, Melchionda S, D'Agruma L, Govea N, Milá M, Monica MD, Lutfi J, Shohat M, Mansfield E, Delgrosso K, Rappaport E, Surrey S, Fortina P (1997) Connexin 26 mutations associated with the most common form of nonsyndromic neurosensory autosomal recessive deafness (DFNB1) in Mediterraneans. Hum Mol Genet 6:1605-1609 